\title{
Leonard, P., \& Wilde, R. (2019). Getting in and Getting on in the Youth Labour Market: Governing Young People's Employability in Regional Context. Bristol: Policy Press.
}

\author{
Liam Wrigley $^{1}$
}

Received: 16 January 2021 / Revised: 26 January 2021 / Accepted: 27 January 2021/

Published online: 12 February 2021

(C) The Author(s), under exclusive licence to Springer Nature Singapore Pte Ltd. part of Springer Nature 2021

Youth unemployment and discourses of employability have been of significant concern for several decades. Amongst the debate from policy makers, government and academic researchers, Leonard and Wilde (2019) have produced a pathbreaking and impressively succinct text, regarding regional and national youth labour market concerns. Gathered from four distinct research projects (carried out from 2014 to 2017), Leonard and Wilde (2019) have crafted and artfully synthesised rich in-depth ethnographic research, concerning dominant regional employability programmes in England and Scotland. Under the influence of Foucauldian thought, Leonard and Wilde (2019) impressively utilise Foucault's (1991) concept of 'governmentality' as a theoretical anchor throughout all six chapters. As I have noted elsewhere (Wrigley 2019), despite the linguistical anxieties a Foucauldian approach may pose, the use of Foucault's theoretical appendages has sensitively been weaved into each chapter, in a thoughtprovoking but impressively accessible way. In particular, each chapter grapples with discourses of power and the fashioning of neoliberal subjects inter alia government education and training policy and schemes. At the heart of this argument, the authors interrogate the techniques in which young people are governed by policy transformations. The authors acknowledge Britain's exit from the European Union (EU) and the ongoing impact, of such, on young people's services. At the time of this book entering print, a post-Brexit deal between the EU and UK had yet to be reached.

Each chapter corresponds to a diverse range of insightful youth labour market projects. The authors undertook an impressive 54 in-depth interviews with young people (age 16-28) and 55 interviews with youth practitioners. Throughout, Leonard and Wilde (2019) respectfully engage with the work of Steven Roberts $(2011,2012)$ and a host of other esteemed scholars in the field, notably, Russell et al.' (2011)

Liam Wrigley

lmwrigley1@ sheffield.ac.uk

1 The University of Sheffield, Sheffield, UK 
longitudinal ethnography of young people on E2E (Entry to Employment) programmes. The authors set their stall, in chapter one with an introduction to salient themes and debates within the youth labour market. They postulate the intersecting strategies that emerge from working with employment experience schemes/providers, youth professionals and young people from diverse range of social backgrounds. The authors capture conservative government that led cuts to state welfare in England. Leonard and Wilde (2019) sensitively map the increase of 'workfare' as a method of welfare conditionality. Critically, they suggest that such 'schemes may function only to reproduce, or further entrench, social inequalities and vulnerability to ongoing liminality and risk' $(2019$, p. 3$)$.

The book is then split across the ethnographic fieldwork encounters throughout chapter two to six. Chapter two delves into the crux of fieldwork undertaken in the North East of England, regarding employability. Such programmes in the North East consist of local enterprise partnerships, funded by the EU. The authors unpack the terrain of some post-industrial communities in the North East, notably, working-class young people who have either had periods of being not in education, employment or training (NEET) or transitions that segue between short term and precarious (un)/ employment. Leonard and Wilde (2019) assert important findings here, concerning the lack of consideration from policymakers in relation to domestic care and childcare arrangements vis-à-vis young people who were looking to re-engage with the labour market. The book also scopes the utilisation of localised job seeking social networks, which notably are geographically marginalised and heavily feature close strong social ties of family/friends and youth professionals providing brokerage between opportunities.

Departing onto another ethnographic study, the authors explore entrepreneurship programmes on the South Coast of England in chapter three. Interestingly, there is a comparison between two programmes here, one aimed at university students and the other aimed at young people who are at risk of becoming long term unemployed. Here, Leonard and Wilde (2019) sophistically demonstrate the stark gendered differences in entrepreneurship, with the male participants more likely to be receptive to such. The authors enrich their analysis of gender through Foucault's concept of governmentality and postmodern youth transitions' literature regarding risk biographies.

Chapter four presents the research undertaken about internships in London. The book develops the social class-based differences in internships, with young people from middle class families possessing more advantageous job-seeking networks, which could propel future employment opportunities. Indeed, Leonard and Wilde (2019) articulate how such interns have, however, internalised highly performative subjectivities, embodiment of neoliberal vocabularies and docility (Foucault 1991), within the workforce. Chapter five then moves on to a volunteering programme in Glasgow, Scotland. The authors impressively introduce the Scottish context, which differs from the previous chapters based in England. The paradox of volunteering workfare is discussed, and this ethnographic case study highlights how trainers and youth professionals have become embedded in an outcome-based culture (see also de St Croix 2018; McPherson 2019), which attempts to enable transitions towards education, employment and training. Chapter six serves as a conclusion and succinctly calibrates the previous chapters together, developing upon the concepts of liminality and risk in all of the young people studied within this text. 
It is commendable how the authors acknowledge the shortcomings of this book, such as the absence of a longitudinal lens. Leonard and Wilde (2019) have created a text where each chapter could act as a standalone piece, which is particularly impressive. Having been published prior to the COVID-19 pandemic, this book still gives ample food for thought on the future direction of the youth labour market in the backdrop of austerity and Brexit. The theoretical use of Foucault is original and consistent. Overall, this book is a welcomed addition in understanding the contemporary youth labour market. This text is an accessible read and would be of interest to youth professionals, non-government organisations (NGOs) and a variety of academic audiences, such as those working within the Sociology of Youth and Education. Leonard and Wilde (2019) should be applauded for creating such an insightful text.

\section{Declarations}

Conflict of Interest The author declares no competing interests.

\section{References}

de St Croix T (2018) Youth work, performativity and the new youth impact agenda: getting paid for numbers? J Educ Policy 33(3):414 438

Foucault M (1991) The Foucault effect: Studies in governmentality. University of Chicago Press, Chicago

Leonard, P., \& Wilde, R. (2019). Getting in and getting on in the youth labour market: Governing young people's employability in regional context. Bristol: Policy Press.

McPherson C (2019) 'It's just so much better than school': the redemptive qualities of further education and youth work for working-class young people in Edinburgh, Scotland. J Youth Stud 23(3):307-322

Roberts S (2011) Beyond 'NEET' and 'tidy' pathways: considering the 'missing middle' of youth transition studies. J Youth Stud 14(1):21-39

Roberts S (2012) One step forward, one step Beck: a contribution to the ongoing conceptual debate in youth studies. J Youth Stud 15(3):389-401

Russell L, Simmons R, Thompson R (2011) Ordinary lives: an ethnographic study of young people attending Entry to Employment programmes. J Educ Work 24(5):477-499

Wrigley L (2019) (Un)Happy 21st Birthday NEET! A Genealogical approach to understanding young people not in education employment or training. Youth \& Policy. [Online] URL: https://www.youthandpolicy. org/articles/unhappy-21st-birthday-neet/ 